\title{
Strategies for Inheritance of Regional Music Culture in Music Education in Primary and Middle Schools
}

\author{
Wang Danqin \\ Zhejiang Conservatory of Music, Hangzhou City Zhejiang Province 310024
}

Keywords: regional music culture; music education; primary and middle schools

\begin{abstract}
Music education in primary and middle schools is considered to be the basic territory of inheriting and carrying forward the Chinese traditional culture, and it has become an important task for music teachers in primary and middle schools to take the responsibility of protecting and inheriting the regional music culture under the tide of globalization. Regional music culture is one of the most simple and sincere condensation and symbol of the connotation and life emotion of soil and water, which is an important part of regional culture. The dissemination of regional music culture is an unshirkable task for music teachers in primary and middle schools. This article tries to explore the inheritance of regional music culture in the primary and middle schools from three dimensions, namely the school, the teacher, the teaching material and the curriculum, to promote the development of music education in primary and secondary schools.
\end{abstract}

\section{Introduction}

In 2001, the Ministry of Education formulated the "Compulsory Education Music Curriculum Standards" to explain the basic concepts of music courses in primary and secondary schools, and proposed that "the traditional music of all ethnic groups in China should be regarded as an important part of music teaching." By studying the Chinese traditional music of all ethnic groups, students are familiar with and love the music culture of the motherland, which is beneficial to enhancing national consciousness and cultivating patriotic sentiments." Regional music culture, which is an important part of Chinese traditional culture, plays an irreplaceable role in shaping national character and promoting national cultural innovation. Primary and secondary education is the basic territory of popularizing national culture, while music education in primary and middle schools is an important channel for disseminating and inheriting regional music culture. The blind pursuit of foreign culture and the lack of local cultural identity are bound to cause great impact on the spread and inheritance of regional music culture in primary and secondary schools. How to protect and inherit the regional music culture has become an important issue for every music educator, especially for music teachers in primary and middle schools. This article tries to explore some strategies to inherit regional music culture in the primary and middle schools from three dimensions, namely the school, the teacher, the teaching material and the curriculum, to promote the development of music education in primary and secondary schools.

\section{Schools should transform educational philosophy and reconstruct the education system}

In the same cultural group, regional music culture has not only the commonality formed in history, but also the unique characteristics of different nationalities and regions, so that it has its characteristics of nationality, richness, diversity and regionality. However, there has been a tendency for a long time for music educators in China to explore the so-called advanced music education theory in the West. They ignore the concern for the national folk music culture and the rich national folk music culture resources. At the same time, the blind admiration of the Western concept has caused a misunderstanding of the regional music culture, and it is considered to be "not a place to be elegant”, which has largely hindered the cognition and understanding of regional music culture. The misunderstanding of the regional music culture will inevitably affect the protection and inheritance of regional music culture. Primary and secondary education is the basic stage of music 
education, and it is the foundation of developing national culture and establishing a sense of national music identity. Integrating regional music culture into quality-oriented education in primary and secondary schools not only enhances the aesthetic appreciation ability of primary and secondary school students, but also contributes to the transmission of aesthetic taste and patriotism of the Chinese nation. The regional music culture can be presented in a live state by its introduction in primary and secondary music classrooms, and recorded with modern technology, which will undoubtedly enable the ancient national culture to be preserved and continued forever.

It is necessary for regional music culture to introduce new educational ideas as a support for entering the classroom of primary and secondary schools. First of all, schools should make clear the responsibility of compulsory education in protecting and inheriting regional music culture. The ultimate goal of education is not only to impart scientific and cultural knowledge, but also to shoulder the important task of inheriting national culture. School administrators and educators should elevate their educational concepts to the height of rebuilding national culture, maintain their ideological objectivity and calmness towards foreign cultures, and identify and avoid the adverse and negative impact of globalization on national cultures. By actively disseminating and carrying forward the excellent national traditional culture, we can effectively stimulate the patriotic feelings of primary and secondary school students, and build up national self-confidence and pride. Only in this way can we surmount obstacles and break through barriers, so that the regional music culture can be better protected and inherited by means of primary and secondary education. Secondly, the implementation of the "Compulsory Education Music Curriculum Standards" proposed that local and schools should develop some music curriculum resources with characteristics of regionality, ethnicity and school by combining the local human geographical environment and national cultural traditions. Local folk music(especially the music items in intangible cultural heritage)should be applied into the music curriculum so that students can be nurtured by the national music culture from an early age and have a sense of inheriting the national music culture.

Schools should make practical exploration on the inheritance of regional music culture from the aspects of training objectives, curriculum, teaching contents and methods, and artistic practice, in accordance with their own regional characteristics, to fully tap and utilize regional music culture resources and enrich regional culture and national culture.

The teaching mode and the artistic practice mode should be improved according to the local conditions and the school conditions, so that the regional music culture resources and the school established education system can be effectively docked, and finally the music teaching quality and the personnel training quality of primary and secondary schools can be effectively improved, and better serve to carry forward the Chinese traditional culture.

\section{Teachers should open up teaching horizons and enhance professionalism}

Regional music culture is a treasure of national folk art. It essentially reflects the living state, aesthetic purport and emotional sustenance of a region or a nation to some extent. It indirectly influences the spiritual growth of primary and secondary school students with its own unique affinity and appeal, and cultivates their national self-esteem, pride and national cohesion.

Music teachers in primary and secondary schools are the backbone of inheriting regional music and culture. They have the responsibility to guide students to taste and appreciate the brilliance of national folk music, to feel and appreciate the unique charm reflected by national folk music, and to help students establish a more complete and clear concept of national music and culture. Only in this way can students acquire a good sense of identification with the national culture and realize the internal docking with the rhythm of national music in the spiritual level.

First of all, music teachers in primary and secondary schools should have certain knowledge of national music. However, as far as the current situation is concerned, most of the music teachers in primary and secondary schools, especially young teachers, do not know enough about folk music, and few of them do their best to collect music materials from the folk. In order to better play a leading role in the protection and inheritance of regional music and culture, music teachers in primary and secondary schools should strengthen their national aesthetic awareness, attach 
importance to the promotion of personal theoretical literacy, consciously explore and supplement the missing knowledge of national folk music and culture, and strengthen identification to national music education through further study, training, folk style, art participation.

Secondly, teachers should adjust the teaching mode in music classes in time. Teachers when teaching music should make full use of modern video and network technology, to help students better understand the rich musical materials contained in the regional culture and understand the historical origins and cultural connotations related to them. Teachers can also break the single closed teaching mode and extend the classroom to the large classrooms of folk music and culture, such as folk museum, intangible cultural heritage protection center, mass art museum, folk art groups, etc. They can lead primary and secondary school students out of the campus by visiting museums, visiting artists, observing performances and participating in folk life. In this way, students can be guided to improve their awareness of regional music culture and lay a good cognitive foundation for inheritance and innovation.

\section{Resources advantage and regional characteristics of teaching materials should be considered when compiling materials and implementing curriculum}

Teaching materials are the blueprint and the main basis for teachers to carry out curriculum teaching. The compilation of music textbooks for primary and secondary schools, both the creative implementation of national curriculum and the characteristic setting of local curriculum and school curriculum, should give full play to the resource advantages of local and school. In the process of compiling and revising music textbooks, the effective use of regional music and cultural resources should be strengthened. The excellent regional music and cultural resources, which embody national spirit and highlight regional characteristics, and conform to the laws of physical and mental development and cognition of primary and secondary school students, should be integrated into the compilation of music textbooks.

But, the compilation of music textbooks depends on the joint participation and cooperation of the government, schools and teachers. Local governments and educational departments should organize educational experts, music teachers and literary and artistic backbone to develop courses and compile teaching materials, and establish a systematic and scientific music teaching system for primary and secondary schools with regional cultural characteristics. On this basis, we should gradually break the situation that the inheritance of regional music culture and primary and secondary education are separated from each other, so that compulsory education can be clearly involved in the protection and inheritance of regional music culture and become the key territory to inherit and carry forward the traditional Chinese culture. In recent years, the Sujiao version of music textbooks has made an example and demonstration in this respect. In the compilation of teaching materials and curriculum design, we should actively incorporate the outstanding achievements of "non-legacy" protection into teaching materials, and select representative arias or repertoires with Jiangsu local characteristics, such as Kunqu Opera, Guqin Art, Suzhou Pingtan and Jiangnan Sizhu, which are suitable for primary and secondary school students to listen to. Music teachers not only shoulder the responsibility of disseminating the basic knowledge of music, but also undertake the task of teaching music performance skills. Therefore, the curriculum needs to take into account the physical and psychological characteristics of primary and secondary school students and their cognitive rule, to set teaching objectives suitable for different ages and grades. At the same time, on the basis of popularization of knowledge and appreciation of music, we should focus on the cultivation of practical ability and gradually cultivate and improve the ability of singing and playing by accumulating the basic theories of music language, melody and tone belonging to our own nationality and region.

Most primary and middle school students study in the local area, and have a certain degree of familiarity in regional dialects and folk culture. Schools can take advantage of locality, and select a music with regional characteristic into classroom teaching, and develop a series of textbooks or course with this characteristic. Teaching materials should have the trait that guides the primary and middle school students to recognize and love the regional music culture from various aspects and 
makes a firm determination to protect and inherit it. First of all, schools should attach importance to the construction of campus culture and create a good atmosphere for traditional music education. Campus radio and multimedia platform can be used to hold regular regional music lectures, folk music exhibitions and broadcasting activities to publicize regional music and cultural resources, so that primary and secondary school students can be immersed in excellent traditional music culture in a good atmosphere. Secondly, extra-curricular resources are also powerful repositories of knowledge. Music knowledge contest and other related activities can be carried out to broaden the vision of national music knowledge of primary and secondary school students. And campus music groups such as choirs, folk bands can also be built to improve music practice ability, and to develop students' ability of feeling, appreciation and performance. In addition, schools should strengthen communication and interaction with society, and regularly lead primary and secondary school students out of the campus, to the public to display and publicize regional music and cultural resources, so as to nurture the community and create a situation in which schools and society participate in the protection. We can also invite "non-legacy" inheritors, folk art associations or folk artists to enter into the campus, by the holding of lectures, art exhibitions, imparting skills and other forms, so that primary and secondary school students directly accept the edification of folk music, so as to have a deeper understanding of the charm of regional music culture.

Regional music culture has strong regional characteristics and contains different customs. Different regional music culture also forms the common artistic style and aesthetic taste of Chinese traditional music culture from different aspects. However, in the tide of globalization, emphasizing the protection and inheritance of Chinese traditional culture does not mean that we are closed and self-confident. Huang Xiang-peng, a famous Chinese music theorist, once said that Chinese traditional music is not a narrow, completely closed cultural system from the historical evolution to the existing music reality. It changes in the continuation of artistic life in the constant flow, absorption, fusion. At the same time, it can be able to spread to this day by passing through numerous rocks and ice blockade, experienced a variety of lost threats.

Today, we emphasize the importance of regional music and cultural resources in music education in primary and secondary schools. We should also uphold an open and integrated attitude. The common historical culture, the common regional environment and the common folklore tradition mold our deep feelings towards the country, the nation and the hometown. This emotion is a kind of emotion which melts in the blood and is difficult to part from. It is the spiritual pillar and the source of strength of the traditional music culture passed on from generation to generation. Relying on this emotion, the Chinese people shoulder the great responsibility of protecting and inheriting traditional culture. However, limited by this emotion, when facing the traditional music culture, we should persist in extracting the essence from the old and bring forth the new, treat it differently and inherit it with sublation. What's more, we should respect the diversity and diversity of the world music culture, and absorb the excellent cultural achievements of other countries and nations with a calm and realistic attitude and an inclusive spirit. Only in this way can we endow the Chinese traditional culture with the spirit of the times and vigor, and truly enhance the attraction and influence of the Chinese traditional culture.

\section{Conclusion}

As the basic stage of human education, primary and secondary education must bear the responsibility of inheriting excellent culture. In the process of protection and inheritance, teachers should make full use of regional resources and incorporate them into the curriculum system to make the inheritance content concrete. Besides, teachers should timely adjust the teaching mode and reform the teaching methods to diversify the inheritance channels. At last, teachers should make the inheritance model stereoscopic by the joint between classroom teaching and extracurricular activities and the multi-dimensional interactions such as artistic practice and internal and external cooperation.

In the practice of music education, teachers' construction, textbook compilation and the effectiveness of inheritance are constantly reflected, and the reform path that accords with the 
school characteristics and innovative development is explored. Only in this way can the regional music culture carry the boat of music education in primary and secondary schools and get the practical inheritance and development, and can the music education in primary and secondary schools make a great contribution to the development of Chinese excellent traditional culture in the contemporary era, and contribute to the realization of the "Chinese dream" of the great rejuvenation of the Chinese nation.

\section{References}

[1] Huang Xiangpeng. Preservation and Development of Chinese Traditional Music [J]. Chinese Musicology, 1984 (4).

[2] Liu Ruizhi. Role and Practice of Folk Music in Music Teaching in Primary and Secondary Schools [J]. Mass Literature and Art, 2014 (7).

[3] Ministry of Education of the People's Republic of China. Compulsory Education Music Curriculum Standards (2011 edition) [S]. Beijing: Beijing Normal University Press, 2012.

[4] Pang Wanfang. Regional Music and Cultural Resources in Music Education Inheritance in Guangxi Primary and Secondary Schools [J]. Art Exploration, 2012 (5).

[5] Ren Qiuli. Reflection and Exploration on the Inheritance of Regional Music Culture in Music Education in Primary and Secondary Schools [J]. Teacher Education in China, 2013 (3).

[6] Wang Xin. Reflection and Exploration on the Inheritance of Regional Music Culture in Music Education in Primary and Secondary Schools [J]. Teaching and Management, 2016 (21): 89-91.

[7] Wang Xuguang. Analysis of the Inheritance of Regional Music Culture in Primary School Music Education [J] . Journal of Reading and Writing, 2016, 13 (12).

[8] Zhang Yan. The Role of Multicultural Music Education in the Inheritance of Ethnic Music Culture: A Case Study of Ethnic Music Education in Primary and Secondary Schools [J]. Journal of Caili University, 2016, 34 (4): 178-182. 